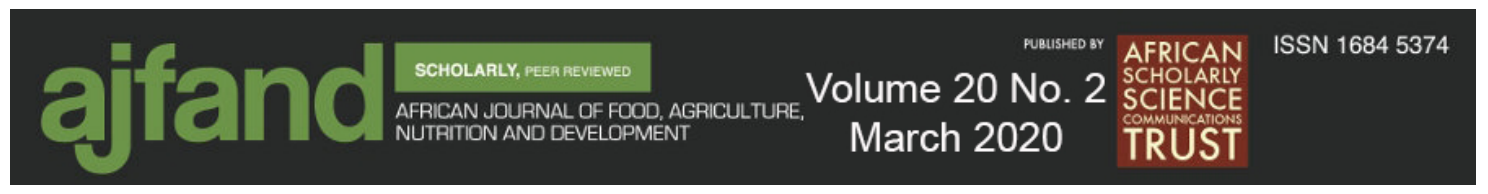

Afr. J. Food Agric. Nutr. Dev. 2020; 20(2): 15455-15473

DOI: 10.18697/ajfand.90.18105

\title{
CHARACTERIZATION OF CARCASS AND PREFERENCE OF CONSUMERS FOR MEAT FROM FOUR STRAINS OF THE TANZANIA SMALL EAST AFRICAN GOATS
}

Semuguruka YD ${ }^{1,2}$, Msalya $G^{1 *}$, Nguluma $\mathrm{AS}^{1}$ and SW Chenyambuga ${ }^{1}$

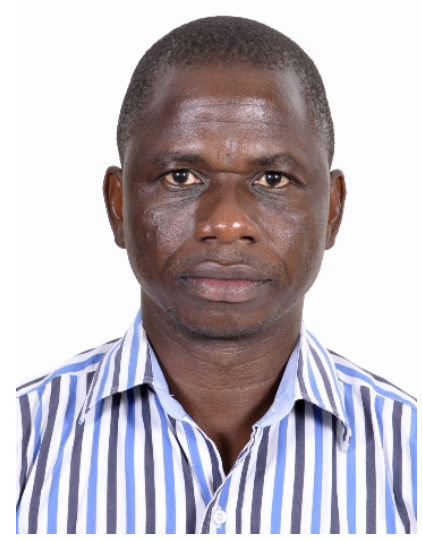

George Msalya

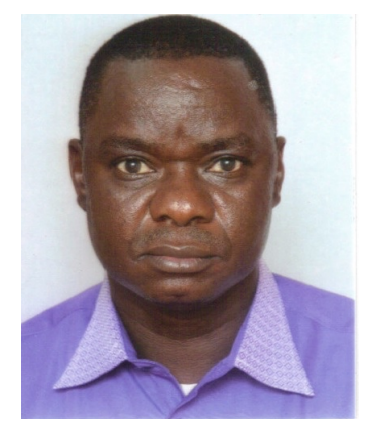

Sebastian Chenyambuga

${ }^{\#}$ Corresponding author email: msalya@sua.ac.tz

${ }^{1}$ Department of Animal, Aquaculture and Range Sciences (DAARS), Sokoine University of Agriculture (SUA), PO Box 3004, Morogoro, Tanzania

${ }^{2}$ Tanzania Livestock Research Institute (TALIRI), PO Box 202, Mpwapwa, Tanzania 


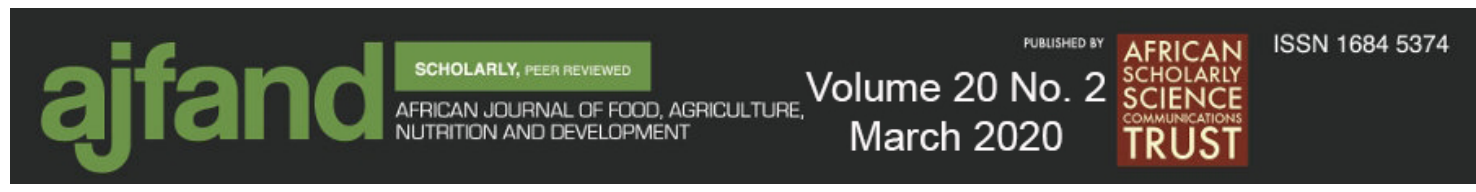

\section{ABSTRACT}

Goats are an integral part of farming systems in rural communities of Tanzania and are second in importance after cattle in the provision of meat, milk, and income. It was estimated that there were 18 million goats in Tanzania in 2018 and the majority (about 98\%) belonged to the Small East African (SEA) breed. The SEA goats are characterized by low productivity due to their inherently low genetic potential for meat and milk leading to low profitability. It is important to design sustainable programmes for increasing productivity of indigenous goats and the first step is to compile status with regard to productivity and to assess market-oriented characteristics for these animals. The aims of this study were: to evaluate carcass characteristics of meat from four strains of the SEA goats namely Gogo, Pare, Sonjo as well as Sukuma, and to assess the preference of consumers for goat meat and meat cuts. Forty eight goats (12 per strain) were involved in this study. The meat was dissected into lean, bone, subcutaneous fat as well as standard joints, and these parts were weighed or measured to obtain the lengths. Longissimus dorsi was sampled from the carcass to determine quality using proximate analysis. Also, a survey was conducted to determine the prices of meat cuts and preferences of consumers using a questionnaire. Averages were compared using the General Linear Model (GLM) procedure of the statistical analysis system. Survey data were coded and analyzed using Statistical Package for Social Sciences (SPSS). Test of significance was based on 5\%. The composition of meat was 65.2 to $67 \%$ lean, 23.5 to $25.7 \%$ bone and 8.4 to $10.7 \%$ fat. Gogo strain had heaviest carcasses $(10.3 \pm 0.45 \mathrm{~kg})$. Dressing Percentage (DP) ranged from 42.1 to $43.5 \%$ and was not significant among strains. Carcass Length (CL), Chest Depth (CD), length of Hind Legs (HLL) and leg circumference were significant among strains and $\mathrm{CD}$ was associated with the weight of the carcass. Fore and hind parts as well as ribs comprised $60 \%$ lean. Crude protein and ash were significant among strains whereas dry matter and fat were not significant. The hind leg was most preferred (52.5\% respondents) because of more meat although was the most priced part ( $9798 \pm 385$ Tanzanian shillings about 4.3US\$). In conclusion, the SEA strains evaluated in this study contained more meat and less bone and fat; there are variations in characteristics and quality of meat among the strains, and consumers prefer the more meaty parts.

Key words: Indigenous goats, Carcass weight, Carcass composition, Meat quality 


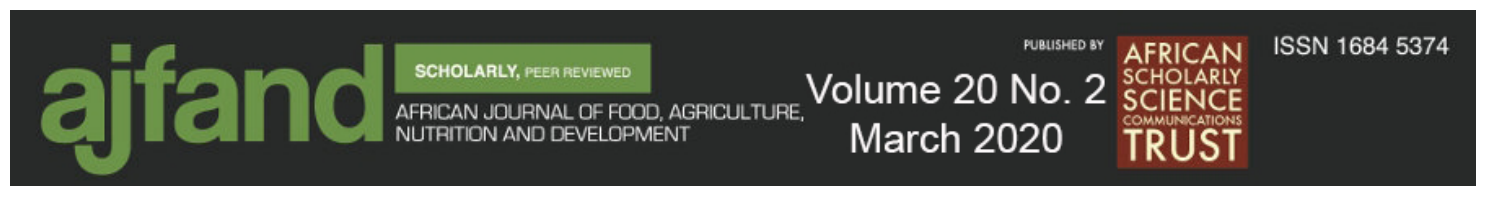

\section{INTRODUCTION}

Goat keeping forms an important and essential part of smallholder agriculture in Tanzania and is undertaken mainly by agro-pastoralists, pastoralists and farmers engaged in mixed farming. It is estimated that $30 \%$ of the agricultural households in Tanzania keep goats [1]. The advantages of goats over other livestock species in traditional farming systems include their small size, low initial costs, rapid turnover and efficient conversion of feed resources not directly eaten by man [2]. Majority of goats in Tanzania are indigenous belonging to the Small East African (SEA) breed, which is composed of many strains that are widely distributed in all agro-ecological zones of the country [1]. Although they have not been exhaustively characterized, the SEA animals have different phenotypic characteristics that identify them into different types (strains) including Newala, Ujiji, Sonjo, Pare, Gogo and Sukuma. The distribution pattern of these strains reflects differences in their adaptability to local conditions and preferences of their traditional keepers. For instance, the Ujiji goats are found in the western zone near Lake Tanganyika, while Sukuma goats are found in the Lake zone, south of Lake Victoria. Maasai, Pare and Sonjo are found in the northern zone, while Gogo and Newala goats are found in the central zone and southern zone, respectively. The SEA goats are mainly raised for meat production although they are milked in some parts of the country.

Goat meat also known as chevon is preferred by many people because of its meatiness, tenderness, juiciness compared to other red meats [3]. About $30 \%$ of meat consumed in Africa is from goat and it is the topmost meat preferred by people [4]. In Tanzania, chevon and mutton contribute $22 \%$ of the national meat supply [1]. Consumption of goat meat has been a norm of the people in the rural areas of Africa since time immemorial particularly during family reunions, holidays and religious or traditional gatherings [5]. Recently, consumption of goat meat has increased in all major towns of Tanzania and this is linked to increased income and purchasing power of the local communities, the growth of tourism, expanding mining industries, and establishment of international hotels in Tanzania $[2,6]$. Moreover, there are emerging international export markets in the Persian Gulf countries, Madagascar and the Comoro Islands. The increase in demand creates a market opportunity for goats kept by pastoralists and agro-pastoralists of Tanzania. Therefore, the SEA goats have a potential for increasing income of the livestock keepers in rural areas because of the readily available and expanding markets. However, the production of enough quantity and meat of high quality which can meet the requirements of the domestic and international markets is of paramount importance.

In Tanzania, strain or breed's specific data for meat characteristics or meat quality are not readily available. Previous studies have concentrated on the relationship between meat characteristics or quality and rearing or feeding systems, comparisons of mixed local goats (not specific strain) with the crossbred goats and comparisons between sheep and goats [3, 7-10]. These and other studies including that of Hango et al. [11] have shown that the mixed goats of Tanzania (local unnamed strains and crossbreds) have Carcass Weight (CW) between 8 and 10kg and Dressing Percentage (DP) less than $50 \%$. Meat attributes for these goats were also determined. Meat characteristics and quality attributes are said to be influenced by many factors including age, breed and management practices of the animals. In this study, we collected specific information on meat 


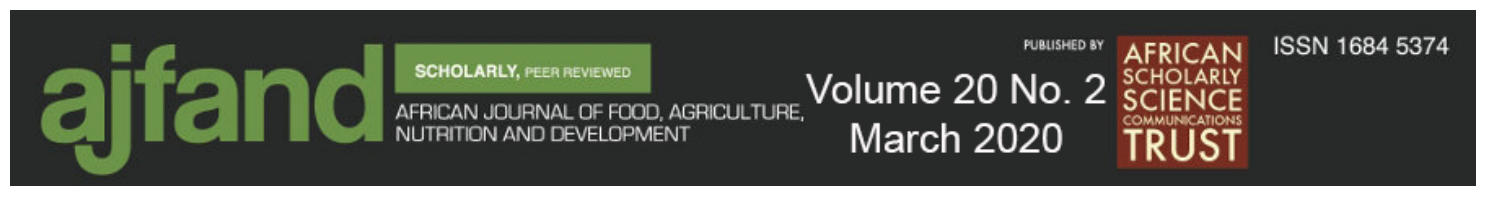

characteristics or quality attributes for specific strains or breeds of goats in different management environments. One study by Mushi et al. [10] showed that most of these goats were slaughtered at the age of three to five years when they have reached live Body Weight (BW) between 20 and $30 \mathrm{~kg}$. Differences such as this may affect the characteristics and quality of goat meat differently. Although the SEA goats are diverse with distinct features, there is little information on the meat characteristics of the different strains. Also, the association between the factors and meat characteristics or attributes for specific strains of these goats is not well documented. The first objective of this study was to obtain data on the characteristics and quality attributes of meat from the sampled strains. For this reason, proximate analyses were carried out with the goal of achieving the first objective of this study.

In international markets, for goat meat, specific qualities are needed. For example, during holidays in the Caribbean, young smelly bucks with an approximate weight of 27 to $36 \mathrm{~kg}$ are demanded by the consumers [12]. In China, goats of such weights are needed during the cooler months of the year [13]. An unpublished report in the Ministry of Agriculture, Livestock Development and Fisheries of Government of Tanzania shows that goats from two regions of Tanzania, namely Simiyu and Singida were highly demanded in goat markets of The United Arab Emirates. There are many other specific requirements for different international markets and these should be met if export opportunities have to be tapped. Locally, there is limited research and documented information on consumers' preference for goat meat [3]. It is not known which strains, age or joint cuts are preferred by the consumers. Thus, our second objective was to assess the preference of consumers for different goat meat parts (joints) and explore the reasons for their preferences at least in the local markets. This is also a strong tool for breeding, management, and marketing of goat strains in terms of specific requirements of the consumers.

\section{MATERIALS AND METHODS}

\section{Description of the study areas}

This study was carried out in four districts of Tanzania, namely Bahi, Ngorongoro, Same and Kwimba where the targeted strains of SEA goats are predominantly reared. These districts are distantly separated such that climate is slightly different and intermingling of the study animals was assumed minimum. In addition, the districts were chosen during a study that was undertaken under the project titled Characterization of the local goats of Tanzania for improved chevon production, implemented by researchers at Sokoine University of Agriculture (SUA) based in Morogoro, Tanzania, and research fellows from the Biotechnology Platform of the South African Agricultural Research Council (ARC). Bahi is a semi-arid district with dry savannah found in central Tanzania at degrees $05^{\circ} 58^{\prime} 0^{\prime \prime} \mathrm{S}$ and $35^{\circ} 21^{\prime} 0^{\prime \prime} \mathrm{E}$. The district receives unimodal erratic rainfall with annual precipitation ranging from 500 to $700 \mathrm{~mm}$. The annual average temperature is $22.6^{\circ} \mathrm{C}$. A large number of goats in Bahi district belong to the Gogo strain. Ngorongoro district is to the north-east of the country at $2^{\circ} 45^{\prime} 0^{\prime}$ ' $\mathrm{S}$ and $35^{\circ} 30^{\circ} 0^{\prime}$ ' $\mathrm{E}$ with both warm and temperate climate. In this district, the rains are bimodal with an average precipitation of $877 \mathrm{~mm}$ per year. The estimated annual temperature is $16.5^{\circ} \mathrm{C}$. A few Sonjo goats are only found in Ngorongoro district. Same, a mountainous district, is also found on the north-eastern part at $4^{\circ} 15^{\prime} 0^{\prime \prime} \mathrm{S}$ and $37^{\circ} 55^{\prime} 0^{\prime \prime} \mathrm{E}$. In this district rainfall is highly variable 


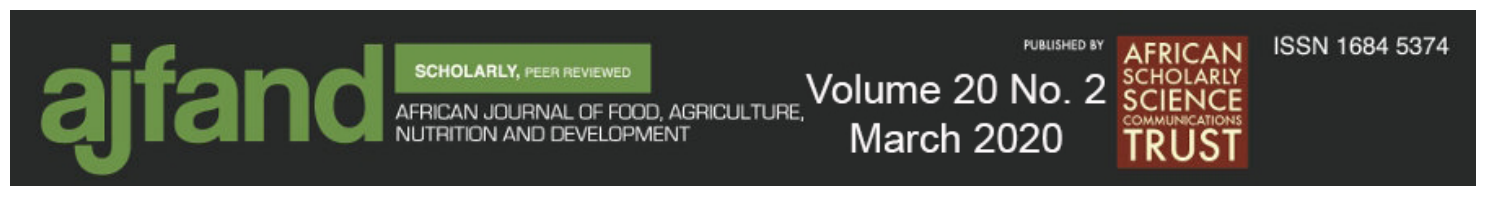

and average annual precipitation is as low as $562 \mathrm{~mm}$. Temperatures are high (up to $40^{\circ} \mathrm{C}$ ) on lowlands but lower $\left(15^{\circ} \mathrm{C}\right.$ to $\left.30^{\circ} \mathrm{C}\right)$ in the mountainous areas. Pare goats were sampled in Same district. Kwimba district is located at $2^{\circ} 55^{\prime} 0^{\prime \prime} \mathrm{S}$ and $33^{\circ} 15^{\prime} 0^{\prime \prime} \mathrm{E}$ degrees in northern Tanzania. Though unreliable, rains are bimodal with annual precipitation between $750 \mathrm{~mm}$ in dry areas and $1200 \mathrm{~mm}$ in wet areas. The average temperature in the district is $15^{\circ} \mathrm{C}$ to $25^{\circ} \mathrm{C}$. The majority of goats in Kwimba district belong to the Sukuma strain. The local goats are surviving well in respective locations and climatic conditions.

\section{Selection of study participants and sampling}

In each district, two distantly located villages (smallest units within the district 30 to $50 \mathrm{~km}$ apart) and with no history of mixing the goats were selected. Farmers and livestock officers in the village were asked to let the researchers know of any introgression of animals in the past, and the villages were selected only when reliable people, in particular elders and extension workers, confirmed the fact of no mixing. Within the farm, owners were asked to identify animals believed to be members of the target strains, while researchers confirmed the animals based on morphological characteristics listed in the literature. This was important to ensure that animals selected represented the required strain but were not closely related. To achieve the first study objective (meat characteristics and meat quality), only goats around slaughter age (1.5 to 2 years) were selected. Age was determined by dentition. Goats identified by owners as members of target strain were sampled from farming households (randomly selected) in the villages. Finally, 48 goats (12 animals per strain or six adult goats per village, three males and three females) were sampled. Before visiting the study sites we obtained permission from the Commission for Science and Technology of Tanzania (COSTECH), a state institution responsible for research ethics. In the district, permission was also received from the Executive Director (DED). In the villages, we asked the verbal consent of farmers after explaining the purpose of our study to be allowed to visit their farms and purchase the goats. Because no samples were taken from humans, no further permission was needed from the National Institute for Medical Research (NIMR).

\section{Goats slaughter and evaluation of meat parts}

Goats were slaughtered in the nearest slaughter slab according to Halal law (prescribed in the Qur'an) and standard commercial procedures. Briefly, the animals were fasted for 24 hours to minimize the effect of gut fill (only water was provided) after visual appraisal, weighed, slaughtered, bled, skinned, eviscerated (separation into carcass and non-carcass components). Separated non-carcass components were blood, head, plaque, liver, kidney, spleen, skin, feet and testicles/udder. Thereafter, hot dressed carcass and the non-carcass components were weighed using a spring balance adjusted to zero each time when weighing was done. From weights, the DP was computed and expressed as a percentage of hot carcass divided by Slaughter Weight (SW). Linear carcass measurements including Carcass Length (CL), Chest Depth (CD), length of Hind Legs (HL), and Hind Leg Circumference (HLC) were taken using a tailor's tape measure. The CL was obtained as the length of the carcass from the thoracic spine to the base of the tail. The CD was measured as the diameter of the carcass at $9^{\text {th }}$ rib internally, whereas HL was determined by measuring the distance between the distal end of tarsal bone and middle of patella. The HLC was the circumference around the widest part of the hind leg at the top cut edge of the pubis. After these measurements, the carcass was divided 


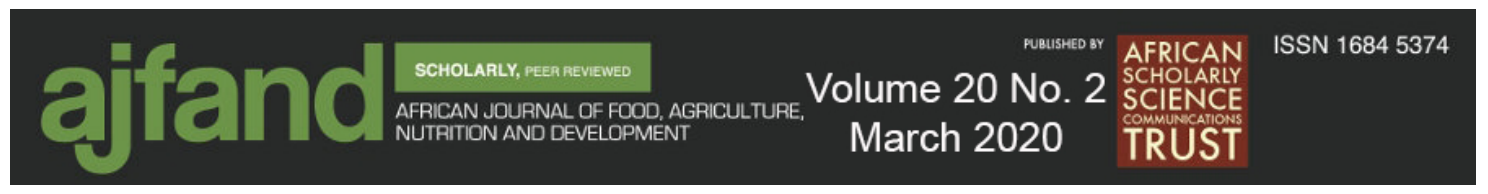

longitudinally into two equal halves (right and left) using a handsaw and knife. One half (left side) was cut into standard joints such as the neck, breast, ribs, loin, chump, hind leg and fore leg. The joints were also weighed separately using a spring balance.

\section{Laboratory analyses for quality examination}

Moreover, dissection was done to separate carcass into lean, bone and fat tissues followed by weighing and computation of composition. To determine the nutritional composition of meat, Longissimus Dorsii (LD) muscle was excised from the left half of carcasses 6 hours post-mortem from which two samples per animal were obtained and used in the evaluation of quality attributes of the carcasses. The samples were kept at $4^{\circ} \mathrm{C}$ maximum for 24 hours during sampling and they were stored at $-20^{\circ} \mathrm{C}$ before analyses. Analyses were done according to the analytical procedure in AOAC [14] and involved the determination of Dry Matter (DM), Crude Protein (CP), Ether Extract (EE) and ash content. Briefly, the DM was obtained after oven drying at $102^{\circ} \mathrm{C}$ until meat was greyish in colour and a formula was used to calculate the parameter. Total protein was estimated after homogenizing about $25 \mathrm{mg}$ of the meat sample and the classical macro-Kjeldhal method of nitrogen analysis was used to determine the crude protein content of meat samples. The protein determination procedure included digestion in acids in particular $\mathrm{H}_{2} \mathrm{SO}_{4}$, incubation at $37^{\circ} \mathrm{C}$ for $1: 30$ hours, distillation using $40 \% \mathrm{NaOH}$, and titration with $\mathrm{HCl}$. Finally, the protein was computed in percentage using a linear formula involving optical density (obtained by spectrophotometry), standard titration values and sample weight. With regard to fat, the Soxhlet method of solvent extraction was used whereby the meat samples were placed in the oven at $100^{\circ} \mathrm{C}$ for 30 minutes and cooled to room temperature in the desiccators for 30 minutes and obtained final weight of the samples using a digital balance. Finally, about $50 \mathrm{ml}$ of diethyl ether was added into the cups containing the samples after extraction and EE was calculated involving weights of the samples and the extract volume. Ash was estimated by incinerating the pre-weighed test sample in a muffle furnace temperature above $550^{\circ} \mathrm{C}$ for about 5 hours and the residues were weighed from which the percentage of ash was calculated. These estimates were done in duplicate. The final value for each of the evaluated parameters (DM, CP, fat and ash) was obtained as an average from the two samples per carcass.

\section{Preference of consumers}

To assess preference of consumers for goat meat cuts, a total of 120 respondents ( 30 per district and 15 per village) voluntarily filled our questionnaire which was structured to answer questions regarding their reasons for preference of goat meat over other types of meat such as beef, pork, and chicken as well as the choices of certain goat meat cuts or joints. The respondents were randomly picked in the sampling villages and were involved in the survey after explaining the objectives of our study by one of the researchers and obtaining their verbal agreement. The list of participants was obtained from a list of farmers in each village compiled by the village administration including the Village Livestock Field Officer (VLFO). The list included only farmers who were engaged in livestock keeping for at least two years. No recording of the agreement was done during meetings with study participants. In the survey, a checklist to survey the prices of the different meat cuts in the same butcher shops was also prepared. General information such as household characteristics, age, sex, education level, marital status and religion of 


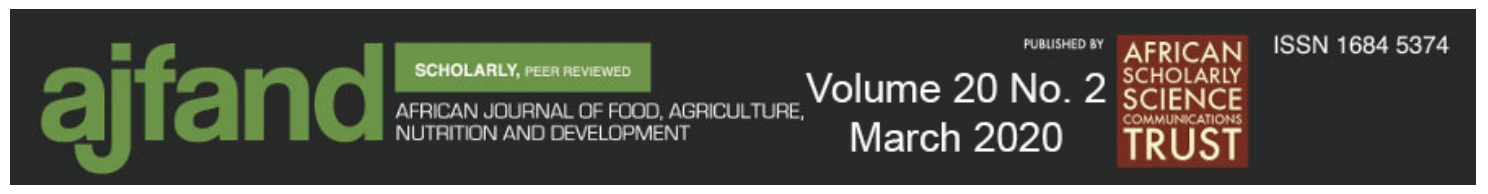

respondents were also collected for the purpose of traceability of data and were included in project reports.

\section{Statistical analyses}

After obtaining the averages for all weights and linear measurements, comparisons among the strains were made using the analysis of variance (ANOVA) according to the General Linear Model (GLM) of the statistical analysis system [15]. Age and sex were ignored on the assumption that all animals (from all strains) were of about the same age (between 1.5 and 2 years) and weight such that no differences were expected in respect to the two factors. $\mathrm{P}<0.05$ were considered significant in our analyses. Survey data were cleaned, coded and analysed using the Statistical Package for Social Science (SPSS) [16]. Descriptive statistics were used to generate means, frequencies and percentages. Preference for five meat types namely beef, goat meat, mutton, pork, and chicken meat was ranked using indices which were calculated using an index formula provided below (a Likert scale numbered between 1 and 5) and which was tested for statistical significance using Chi-square.

Sum of $\left(5 \times\right.$ number of respondents ranked $\left.1^{*}\right)+(4 \times$ number of respondents ranked $\left.2^{*}\right)+\left(3 \times\right.$ number of respondents ranked $\left.3^{*}\right)+(2 \times$ number of respondents

Index $=\frac{\left.\text { ranked } 4^{*}\right)+\left(1 \times \text { number of respondents ranked } 5^{*}\right)}{\left(5 \times \text { total number of respondents ranked } 1^{\mathrm{y}}\right)+(4 \times \text { total number of respondents }}$ ranked $\left.2^{y}\right)+\left(3 \times\right.$ total number of respondents ranked $\left.3^{y}\right)+(2 \times$ total number of respondents ranked $\left.4^{y}\right)+\left(1 \times\right.$ total number of respondents ranked $\left.5^{\mathrm{y}}\right)$

In the mathematical expression, * indicates number of respondents ranking a specific commodity (meat type such as beef, goat meat, mutton, pork, and chicken meat as 1,2 , 3,4 or 5 whereas ${ }^{\mathrm{y}}$ shows number of respondents ranking any commodity as 1, 2, 3, 4 or 5. The reasons for the preference of meat types were listed in the questionnaire by the respondents.

\section{RESULTS AND DISCUSSION}

\section{Goats' slaughter and meat characteristics}

The CW weight ranging from $7.8 \pm 0.45 \mathrm{~kg}$ in Sonjo goats (the lowest) to $10.3 \pm 0.45 \mathrm{~kg}$ in Gogo strain (the highest) and clearly reflected the SWs in each strain. The CW values were significantly different among the four strains. The DP values were lower than $50 \%$ (maximum $43.5 \%$ ) in all strains and were not statistically significant $(\mathrm{P}>0.05)$. Regarding the linear measurements, the highest CL was $43.5 \mathrm{~cm}$ in Sukuma goats and lowest in the Gogo strain $(42.1 \mathrm{~cm})$. The CD was highest in Gogo goats $(28.6 \mathrm{~cm})$ followed by Pare, Sukuma and least in Sonjo strain $(24.4 \mathrm{~cm})$. On the HL parameter, Pare goats scored highest $(24.3 \pm 0.67 \mathrm{~cm})$ than the rest of the strains. Unexpectedly Gogo had the least score on the parameter. The HLC values showed a different pattern in order of Pare goats, Gogo, Sukuma and Sonjo (highest to lowest). All linear measurements were statistically significant $(\mathrm{P}<0.05)$ among strains. Detailed results on these parameters are presented in Table 1. Among all measurements taken, only CD showed a direct relationship with $\mathrm{CW}$ such that the higher the CD the heavier the CW. Results showed that the Gogo were found superior in weights of five joints namely breast, ribs, loin, hind leg and fore leg. 


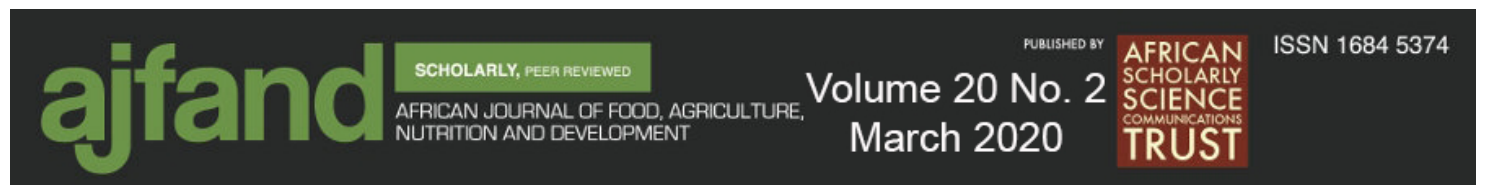

The weight of the neck joint was heaviest in the Sukuma strain whereas the chump was heaviest in the Pare goats (Table 2). As expected, the Sonjo strain was inferior in the weights of all joints. Weights of these joints showed statistical significance $(\mathrm{P}<0.05)$ among strains.

Meat characteristics presented in this study were comparable to those reported in the studies listed above. For example, the CWs reported here were within the ranges of 19 and $22 \mathrm{~kg}$ reported previously by Shija et al. [3] and Hango et al. [11]. In these and other studies including the study by Hazzo et al. [8] values of CW between 7.1 and $10.8 \mathrm{~kg}$ have been obtained. Our results compare well with what is reported in these and other studies in the African continent. In the West African Dwarf and Red Sokoto goats, Msanga et al. [17] reported CWs ranging from 9.7 to $10.25 \mathrm{~kg}$. In Tanzania, the highest CW (12.67kg) was reported by Mushi [18] in SEA goats sampled and slaughtered at one auction market in Central Tanzania. Moreover, the DP in Tanzania and African local goats can be traced. Although highest values (56\%) have been obtained in a few goats populations, many workers in this field agree that DP values in the local goats of Tanzania and Africa in the common extensive management systems have been less than $50 \%[11,18-22]$.

\section{Composition of carcass}

Regarding the composition of the carcass in the SEA goats, between 65.2 and $67 \%$ of the carcasses comprised the muscle, 23.5 to $25.7 \%$ was bone and 8.4 to $10.7 \%$ was fat (Table 3). Carcasses from Gogo goats had more muscle and fat than carcasses from Pare, Sonjo and Sukuma goats. Carcasses from Sonjo strain had significantly lower values $(\mathrm{P}<0.05)$ of muscle and bones compared to the rest of the strains. The amount of fat was not significant among the strains (Table 3). With respect to the nutritional values of the meat, it was found that DM was above 25 in all animals and was not significant in the strains. The CP was above 20\% but highest in Sukuma (22.4\%) compared to the rest of the animals. There was a significant difference in $\mathrm{CP}$ among the four strains. Concerning fat in the meat, values ranging from 0.13 to $0.21 \%$ were determined. These were not statistically significant among strains. As for ash, values were above 4\%, highest in Sonjo $(4.43 \%)$, lowest in Sukuma (4.01\%) and were significantly different among strains (Table 4).

The values for slaughter characteristics, in particular, the linear measurements in the present study were slightly higher compared to past reports. Specifically, the largest value for CD in our goats was greater than $26.3 \mathrm{~cm}$ as obtained by Mushi [18] in unnamed SEA goats in central Tanzania, $22.9 \mathrm{~cm}$ in crosses of SEA and Norwegian Landrace or NL goats [8], $18.3 \mathrm{~cm}$ in West African Dwarf goats, and $17.7 \mathrm{~cm}$ in Red Sokoto goats [17]. Referring to HLL, our values were a little lower compared to those reported in these publications $(26.9$ to $37.9 \mathrm{~cm})$. Differences were also obtained in weights of joints and percentage composition of the tissues among our goats and between them and goats analyzed by previously workers. The fore leg, hind leg and ribs were shown to contribute $63.2 \%$ of the carcass in SEA goats of central Tanzania [18]. The proportion of muscle and fats in the carcasses of goats in Tanzania were respectively shown to range from 54 and $66 \%$ and 8.4 to $10.7 \%$ [8, 23], in which our results fall. In Tanzania, the highest composition of fat $(15.5 \%)$ was reported by Hango et al. [11] in crosses of SEA and 


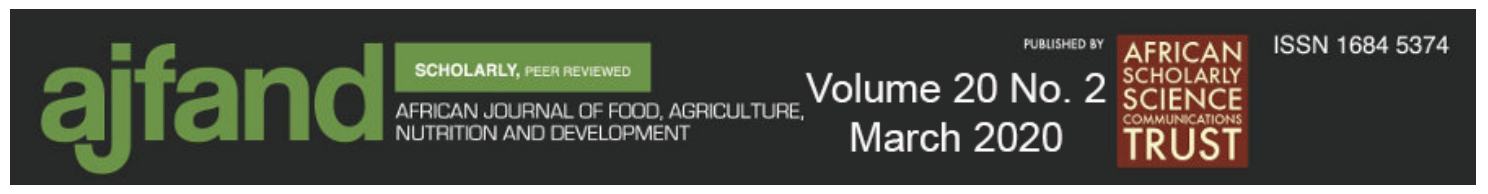

Norwegian Landrace or NL goats. In these studies, the goats were supplemented. Fat content is an important quality determinant of carcasses and has a direct effect on the commercial value of carcasses. Also, fat content influences the organoleptic properties, keeping the quality and nutrient value of meat [4]. The differences in fat content contribute to the sensory difference in characteristics of meat as it affects juiciness, tenderness, and flavor.

With respect to the nutritional values four parameters, namely DM, CP, fat and ash contents of the meat were estimated. Despite the differences noted in our strains in other parameters, the DM content was not significant and compares well with values in earlier reports for fattened SEA goats [23] and other goats elsewhere [5]. Higher DM values $(27.6-32.9 \%)$ have been observed in supplemented Tanzania crossbred [7] and castrated or feedlot goats [24-26]. Also, the CP value which was obtained in this study were in agreement with those reported in earlier works in the local goats in Tanzania and other countries $[5,8,23,26]$. Lower and higher $\mathrm{CP}$ values compared to the ones reported in our study are reported in the literature [19,24,25]. Furthermore, both fat and mineral compositions were in agreement with those published in the findings of previous [23]. Higher values of fat content were reported in supplemented and feedlot goats $[5,8,19,25]$. The discrepancies in various parameters between our goats and those reported previously in literature are worth evaluating and establishing the reasons for them and they could be used to conduct selection and breeding of the local goats in Tanzania and elsewhere. In this study, the Sonjo goats were inferior in many parameters. However, the meat from these goats had the highest ash content than goats in the other strains. This was expected because these goats were sampled from the hot and arid lowland areas of Sale and Loliondo around Lake Natron in Ngorongoro district where the soils are characteristically volcanic and rich in minerals. Moreover, other factors such as breed, age, sex, and stage of growth can affect fat composition in goats. Concerning the noncarcass components, statistical significance was found among our goats and this could also be associated with the same factors. For example, in one study by Berihun et al. [27] it was shown that large-sized goats had higher stomach weight.

\section{Non-carcass components}

The weights of non-carcass components involving several organs were measured and are presented in Table 5. It can be observed that the Gogo goats had higher values for different organs including blood, head, liver, kidney and spleen compared to the other strains. The Pare goats had the heaviest skin while the Sonjo and Sukuma goats were superior in feet and testicle weights, respectively. The weights of non-carcass components were significantly different $(\mathrm{P}<0.05)$ among the strains.

\section{Preference of consumers}

The preference of consumers for different meat types including beef, goat meat, mutton, pork and chicken were ranked and found that goat meat was highly preferred over other types of meat. These results were based on the index scores and ranks in brackets as follows; 0.261 (2) for Beef, 0.275 (1) for goat meat, 0.133 (5) for mutton, 0.223 (3) for pork and 0.210 (4) for chicken. Factors for the preference of goat meat was due to the attributes ranked in order of taste, tenderness, juiciness, less fat and marbling over other meat types. Regarding the preference of the joints, hind leg was the most preferred meat 


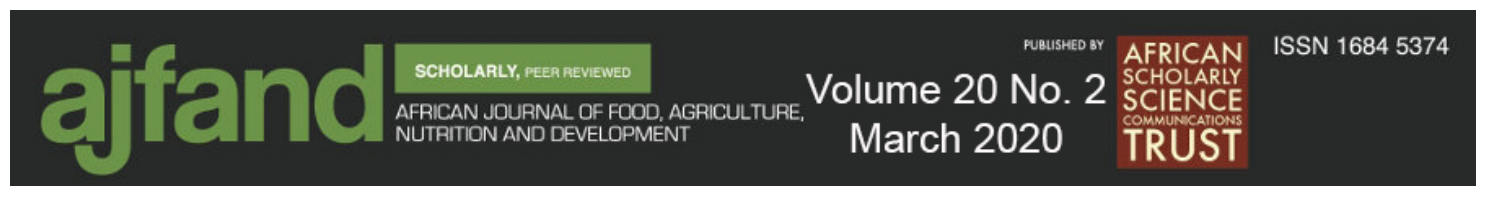

as suggested by over $52.5 \%$ of our respondents and the major reason for this choice was the amount of meat in the joint cut. Although it was preferred by the majority, hind leg was the most priced part of the meat (Table 6). Other joints that were also preferred on the same grounds were the fore leg, loin, breast meat, ribs and chump. The remaining parts (mainly non-edible parts or offals) were preferred by a low number of people mainly due to the low prices (Table 6).

Preferences of the farmers for goat meat reconfirmed an argument that probably goat meat is the top-most preferred meat in Africa and East Asia due to its good taste, tenderness and possibly its convenience or size [28]. In Tanzania and elsewhere there are religious and traditional limitations for the choice of some meats; no wonder pork and mutton were the least selected [29]. Regarding preference of certain meat cuts, the hind leg, fore leg, and rib joints are preferred in Tanzania by consumers because of high lean meat content and this corresponds well to the criterion used by consumers to buy meat from retail butchers [10]. In addition, the hind limb of goats seems to be suitable for the production of high-value cuts because it has low fat and high lean content and it is perceived to be an indicator of meat quality as far as retailers are concerned [19]. However, in Tanzania, these cuts have high prices compared to other cuts. On some occasions, the cuts can further be split into smaller retail units for easiness of marketing depending on the market where the meat is going to be sold [10]. Consumers are more conscious about their diet and tend to avoid meat with high fat content in preference of leaner meat [19]. In the present study, meat choices were mainly on the basis of leanness and price. While in most western countries, cuts from the hind limb and the dorsal region are of prime value and the breast region is of low value [29], in the present study, the breast meat was ranked fourth.

In general, goats are ranked second in importance after cattle and as valuable animals especially in the poor rural communities in the country. However, information regarding the production or genetic performance of the more than 10 strains of local goats (the majority) is lacking. It is, therefore, difficult to design programmes for selection and breeding of local goats which are known to be low producers of meat and milk [2, 30]. A few earlier studies to generate phenotypic and genotypic information of these goats were based on a limited number of strains (3 to 4 ) and a small number of samples [2, 31, 32 ]. In the field of goat meat attributes and characteristics, previous research efforts have concentrated on improving the slaughter weights of the strains of local goats using concentrates or improved feeding $[9,33]$. Other studies in the same area tried to compare slaughter characteristics or meat quality between the SEA and crossbred goats and between goats and sheep $[3,8,11]$. Therefore, reliable information on specific qualities, meat characteristics and nutritional value of meat from the SEA goats is lacking. There is to need for document more information about these goats, which can be used to obtain specific information or specific attributes of the local goats. This study was, therefore, designed to gather data on slaughter characteristics, the weight of meat parts and joints (meat tissues and special cuts) and the nutritional composition of goat meat in four strains of SEA goats of Tanzania. In addition, we assessed the preference of goat meat over other types of meats as well as preference for meat parts and determined the reasons for these preferences to inform our readers on the potential of goat meat in either nutrition or marketing programs. Information (research findings) presented in this study can be 


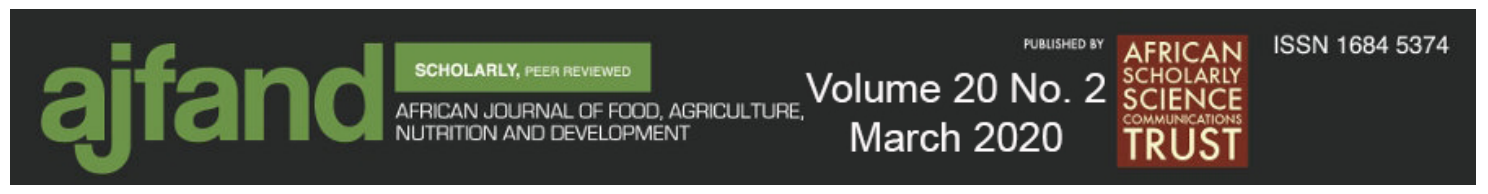

useful in the future evaluation of local goats for selection, breeding or other improvement programmes. For example, it was clearly shown that the Gogo animals have more carcass weight compared to the three other strains involved in this study and at least for this reason the latter can be selected and bred for improved slaughter weights in the Sonjo and Sukuma goats. Moreover, there was a positive relationship between CD and CW in the present study and we recommend future analyses to confirm this fact. Statistical significance revealed in weights of carcass, tissue, joint cuts and non-edible parts among the goats is an indication that the goats may have differences in several slaughter or meat characteristics.

\section{CONCLUSION}

It is shown that there was a significant variation in some meat traits among the four strains of SEA goat strains evaluated in the present study. Significant differences were observed on CW, linear measurements, the composition of tissues, and all non-carcass organs and these suggest that there are variations in these parameters among the SEA goats of Tanzania. This may be the case in these goats in East African countries. The Gogo goats had the highest values on CW $(10.3 \pm 0.45 \mathrm{~kg})$ and CD $(28.6 \mathrm{~cm})$ while other goats had better values on other parameters. The DP values were lower than $50 \%$ in all strains. Carcasses from Sonjo had the lowest values in most of the evaluated parameters. Carcasses from Gogo goats were found superior in weights of five joints namely breast, ribs, loin, hind leg and fore leg. The neck joint was heaviest in the Sukuma strain whereas the chump was heaviest in the Pare goats. The Sonjo strain was inferior in the weights of all joints. Regarding the composition of the carcass in the SEA goats, carcasses from Gogo goats had more muscle and fat than carcasses from Pare, Sonjo and Sukuma goats. Carcasses from Sonjo strain had significantly lower values $(\mathrm{P}<0.05)$ of muscle and bones compared to the rest of the strains. Concerning the nutritional values of the meat, the DM was above 25 in all animals and was not significant in the strains. Carcasses from Sukuma and Pare strains have more muscle and fat content compared to carcasses from Gogo and Sonjo strains. There was a significant difference in CP among the four strains. Findings presented in our study can aid selection, breeding and management improvement programmes and may be one of the useful tools for the characterization of the studied strains. However, we conducted our analyses in only four of the many strains (possibly more than 10) of Tanzania. We, therefore, recommend a national programme for evaluation of all strains and breeds of goats in the country to derive more comprehensive conclusions and concrete recommendations. Moreover, we have shown that consumers prefer goat meat compared to other meats, which it is a positive indicator for future benefits and potential of goats farming Tanzania. We finally suggest further research on how the differences in meat characteristics among the strains can be best utilized to improve breeding and productivity as well as studies on the relationship between characteristics of households or respondents and preference for goat meat or goat meat cuts. 


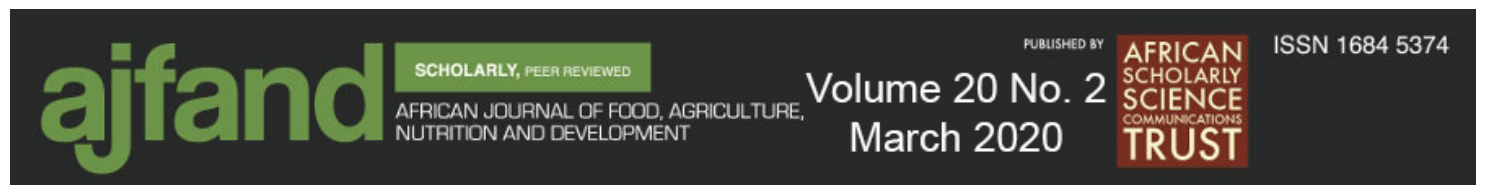

\section{ACKNOWLEDGEMENTS}

This work was jointly supported by the Commission for Science and Technology (COSTECH) of The Government of Tanzania and the National Research Fund (NRF) of The Government of South Africa to the project titled "Characterization of local goats of Tanzania for improved chevon production” Project Number TZ-RSA/JRP/RG.2013.10. Additional support from COSTECH in form of MSc and $\mathrm{PhD}$ scholarships to authors YDS and ANS, respectively is greatly acknowledged. We thank the farmers and consumers in the study districts for their willingness to participate and for willingly availing their animals.

\section{AUTHORS' CONTRIBUTIONS}

YDS, GM and SWC designed the experiments. YDS and ASN carried out the analysis and drafted the manuscript. YDS and ASN did the statistical analyses. YDS, GM, ASN and SWC structured the scientific content. All authors provided editorial suggestions and revisions, and read and approved the final draft.

\section{CONFLICT OF INTEREST DECLARATION}

The authors declare that they have no conflict of interest in this article. 


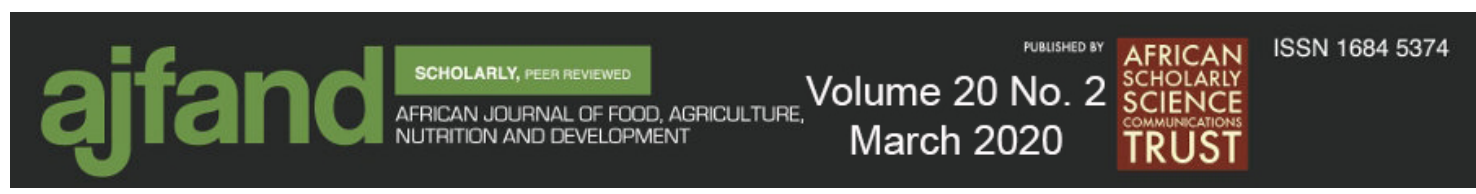

Table 1: Carcass weight, dressing percentage and linear carcass measurements of four strains of goats of Tanzania

\begin{tabular}{lccccccc}
\hline \multirow{2}{*}{ Strain } & \multicolumn{7}{c}{ Carcass characteristics $(\mathrm{LSM} \pm \mathrm{SE})$} \\
& $\mathrm{SW}(\mathrm{kg})$ & $\mathrm{CW}(\mathrm{kg})$ & $\mathrm{DP}(\%)$ & $\mathrm{CL}(\mathrm{cm})$ & $\mathrm{CD}(\mathrm{cm})$ & HLL $(\mathrm{cm})$ & HLC $(\mathrm{cm})$ \\
\hline Gogo & $22.4 \pm 1.11^{\mathrm{a}}$ & $10.3 \pm 0.45^{\mathrm{a}}$ & $42.1 \pm 1.05^{\mathrm{a}}$ & $40.1 \pm 0.87^{\mathrm{a}}$ & $28.6 \pm 0.87^{\mathrm{a}}$ & $21.1 \pm 0.72^{\mathrm{a}}$ & $36.2 \pm 0.84^{\mathrm{a}}$ \\
Pare & $22.0 \pm 1.00^{\mathrm{a}}$ & $9.8 \pm 0.44^{\mathrm{a}}$ & $42.8 \pm 1.02^{\mathrm{a}}$ & $41.1 \pm 0.81^{\mathrm{a}}$ & $25.8 \pm 0.81^{\mathrm{b}}$ & $24.3 \pm 0.67^{\mathrm{b}}$ & $39.7 \pm 0.78^{\mathrm{b}}$ \\
Sonjo & $17.6 \pm 1.06^{\mathrm{b}}$ & $7.8 \pm 0.45^{\mathrm{b}}$ & $42.9 \pm 1.05^{\mathrm{a}}$ & $36.3 \pm 0.83^{\mathrm{b}}$ & $24.4 \pm 0.83^{\mathrm{b}}$ & $22.5 \pm 0.69^{\mathrm{ab}}$ & $31.8 \pm 0.80^{\mathrm{c}}$ \\
Sukuma & $18.8 \pm 1.11^{\mathrm{b}}$ & $8.4 \pm 0.44^{\mathrm{b}}$ & $43.5 \pm 1.01^{\mathrm{a}}$ & $41.6 \pm 0.80^{\mathrm{a}}$ & $24.8 \pm 0.80^{\mathrm{b}}$ & $22.4 \pm 0.66^{\mathrm{ab}}$ & $35.6 \pm 0.77^{\mathrm{a}}$ \\
P-value & 0.0001 & 0.0006 & 0.3501 & 0.0070 & 0.0028 & 0.0038 & 0.0001
\end{tabular}

SW: Slaughter weight; CW: Carcass weight; DP: Dressing percentage; CL: Carcass length; CD: Chest depth; HL: Hind leg length; HLC: Hind leg circumference; LS: Means with different superscripts within a column are statistically significant

Table 2: Average weights of joints $(\mathrm{kg} \pm \mathrm{SE})$ in four strains of SEA goats of Tanzania

\begin{tabular}{lccccccc}
\hline Strain/Joint & Neck & Breast & Ribs & Loin & Chump & Hind leg & Fore leg \\
\hline Gogo & $0.36 \pm 0.02^{\mathrm{a}}$ & $0.36 \pm 0.04^{\mathrm{a}}$ & $1.03 \pm 0.05^{\mathrm{a}}$ & $0.49 \pm 0.03^{\mathrm{a}}$ & $0.42 \pm 0.03^{\mathrm{a}}$ & $1.10 \pm 0.05^{\mathrm{a}}$ & $0.97 \pm 0.05^{\mathrm{a}}$ \\
Pare & $0.33 \pm 0.02^{\mathrm{a}}$ & $0.31 \pm 0.03^{\mathrm{a}}$ & $0.76 \pm 0.05^{\mathrm{b}}$ & $0.38 \pm 0.03^{\mathrm{b}}$ & $0.57 \pm 0.03^{\mathrm{b}}$ & $0.95 \pm 0.05^{\mathrm{b}}$ & $0.89 \pm 0.05^{\mathrm{a}}$ \\
Sonjo & $0.28 \pm 0.02^{\mathrm{b}}$ & $0.20 \pm 0.04^{\mathrm{b}}$ & $0.58 \pm 0.05^{\mathrm{b}}$ & $0.37 \pm 0.03^{\mathrm{b}}$ & $0.37 \pm 0.03^{\mathrm{a}}$ & $0.64 \pm 0.05^{\mathrm{c}}$ & $0.72 \pm 0.05^{\mathrm{b}}$ \\
Sukuma & $0.37 \pm 0.02^{\mathrm{a}}$ & $0.34 \pm 0.03^{\mathrm{a}}$ & $0.76 \pm 0.05^{\mathrm{b}}$ & $0.42 \pm 0.03^{\mathrm{a}}$ & $0.46 \pm 0.03^{\mathrm{a}}$ & $1.01 \pm 0.05^{\mathrm{ab}}$ & $0.84 \pm 0.05^{\mathrm{b}}$ \\
P-value & 0.0238 & 0.0136 & 0.0022 & 0.0237 & 0.0009 & 0.0001 & 0.0186 \\
\hline
\end{tabular}

LS means with different superscripts within column are statistically significant 


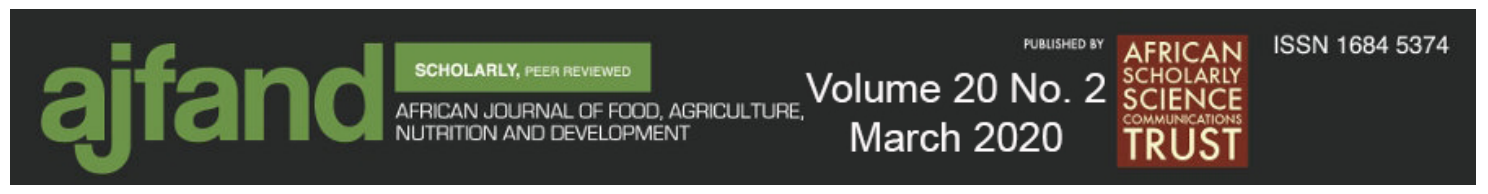

Table 3: Weights of tissues (muscle, bones and fat) in $\mathrm{kg} \pm \mathrm{SE}$ and their percentages in the carcasses of four strains of SEA goats of Tanzania

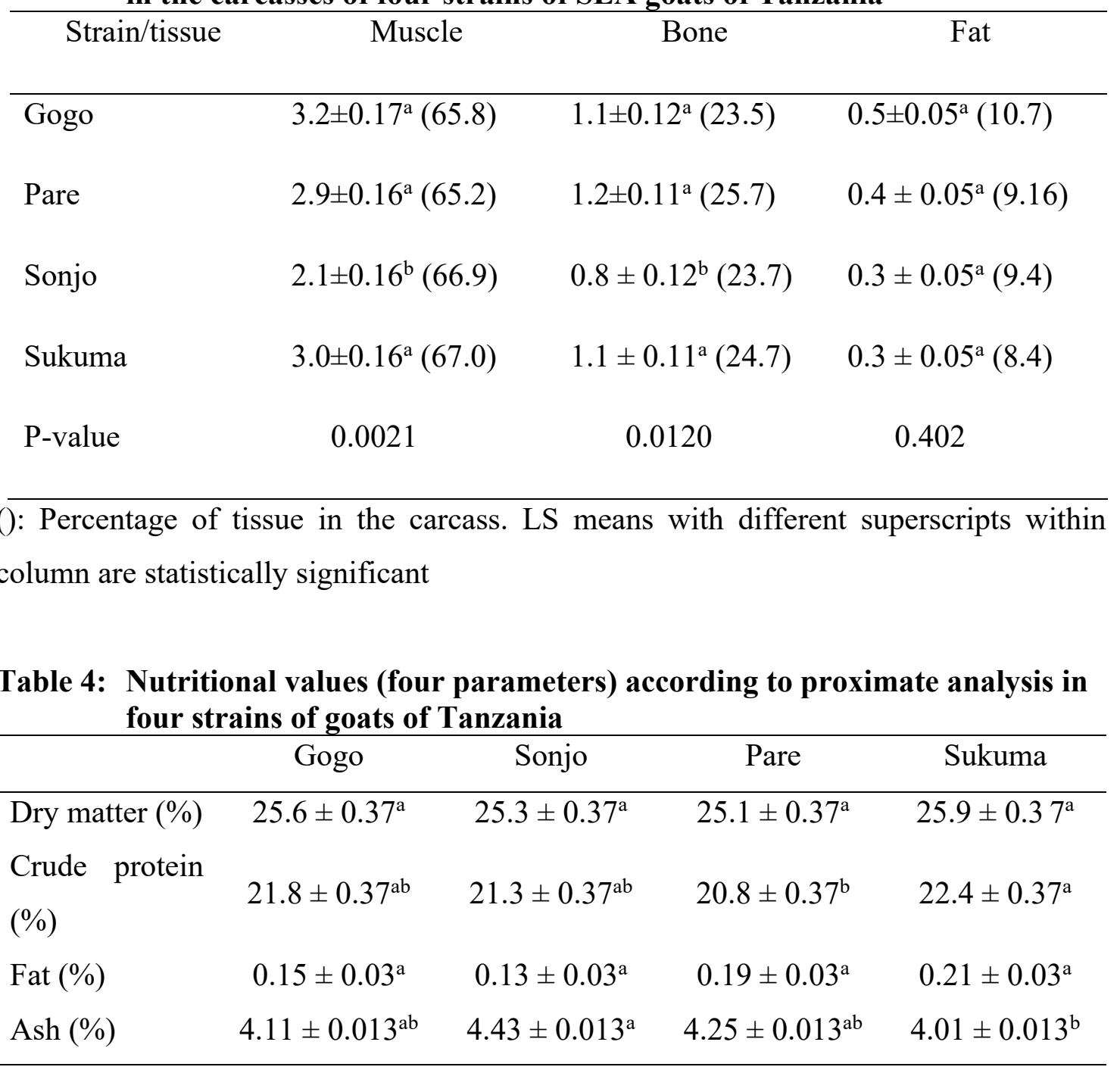




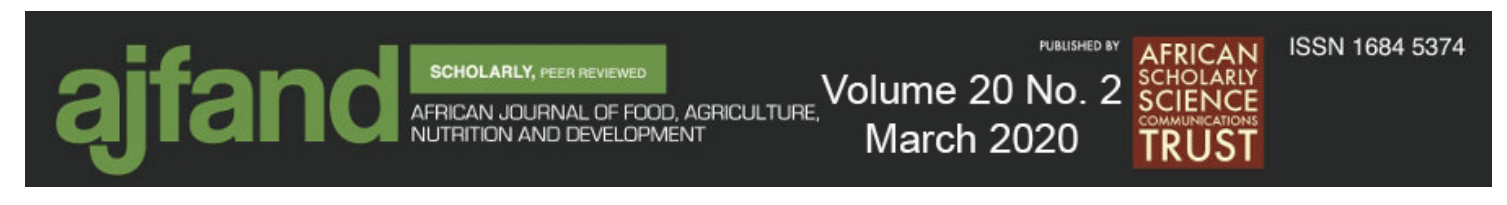

Table 5: Weights of non-carcass components $(\mathrm{kg} \pm \mathrm{SE})$ in four strains of SEA goats of Tanzania

\begin{tabular}{|c|c|c|c|c|c|c|c|c|c|c|c|}
\hline Strain & Blood & Head & Plaque & Liver & Kidney & Spleen & GIT full & GIT empty & Skin & Feet & Testicles \\
\hline 1 & $0.71 \pm 0.07^{\mathrm{a}}$ & $1.84 \pm 0.11^{\mathrm{a}}$ & $0.39 \pm 0.03^{\mathrm{a}}$ & $0.86 \pm 0.07^{\mathrm{a}}$ & $0.20 \pm 0.01^{\mathrm{a}}$ & $0.17 \pm 0.01^{\mathrm{a}}$ & $3.7 \pm 0.16^{\mathrm{ab}}$ & $1.3 \pm 0.07^{\mathrm{a}}$ & $1.3 \pm 0.12^{\mathrm{a}}$ & $0.42 \pm 0.05^{\mathrm{a}}$ & $0.19 \pm 0.02^{\mathrm{a}}$ \\
\hline 2 & $0.53 \pm 0.07^{\mathrm{b}}$ & $1.76 \pm 0.10^{\mathrm{a}}$ & $0.38 \pm 0.03^{\mathrm{a}}$ & $0.56 \pm 0.07^{b}$ & $0.14 \pm 0.01^{b}$ & $0.08 \pm 0.01^{b}$ & $3.8 \pm 0.16^{\mathrm{a}}$ & $1.7 \pm 0.07^{b}$ & $1.7 \pm 0.12^{b}$ & $0.70 \pm 0.05^{b}$ & $0.19 \pm 0.02^{\mathrm{a}}$ \\
\hline 3 & $0.50 \pm 0.07^{b}$ & $0.97 \pm 0.10^{\mathrm{b}}$ & $0.29 \pm 0.03^{b}$ & $0.42 \pm 0.07^{b}$ & $0.12 \pm 0.01^{\mathrm{c}}$ & $0.06 \pm 0.01^{b}$ & $3.5 \pm 0.16^{\mathrm{ab}}$ & $1.2 \pm 0.07^{\mathrm{a}}$ & $1.7 \pm 0.12^{\mathrm{b}}$ & $0.70 \pm 0.05^{\mathrm{b}}$ & $0.26 \pm 0.02^{\mathrm{b}}$ \\
\hline 4 & $0.71 \pm 0.06^{\mathrm{a}}$ & $1.31 \pm 0.10^{\mathrm{c}}$ & $0.41 \pm 0.03^{\mathrm{a}}$ & $0.41 \pm 0.07^{\mathrm{b}}$ & $0.08 \pm 0.01^{\mathrm{d}}$ & $0.06 \pm 0.01^{b}$ & $3.3 \pm 0.16^{\mathrm{b}}$ & $1.4 \pm 0.07^{\mathrm{a}}$ & $1.3 \pm 0.12^{\mathrm{a}}$ & $0.56 \pm 0.05^{\mathrm{a}}$ & $0.18 \pm 0.02^{\mathrm{a}}$ \\
\hline $\mathrm{P}$ & 0.0001 & 0.0001 & 0.0287 & 0.0001 & 0.0001 & 0.0001 & 0.0312 & 0.0001 & 0.0230 & 0.0001 & 0.0027 \\
\hline
\end{tabular}

1: Gogo; 2: Pare; 3: Sonjo; 4: Sukuma; GIT: Gastric intestinal tract; LSmeans with different superscripts down the column within a factor (i.e. Strains, Sex, Age) differ significantly 


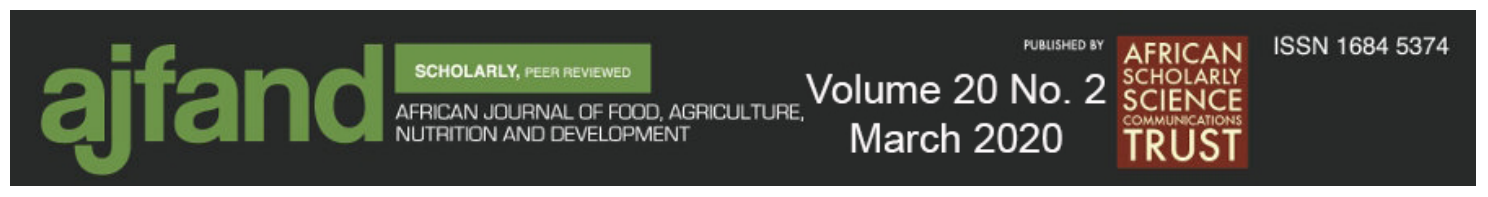

Table 6: Preference of goat meat joints based on number or percentage of respondents and reasons for preference

\begin{tabular}{lccc}
\hline Joint preferred & $\begin{array}{c}\text { Number of } \\
\text { respondents }\end{array}$ & $\begin{array}{c}\text { Percentage of } \\
\text { respondents }\end{array}$ & $\begin{array}{c}\text { Number one reason of } \\
\text { preference }\end{array}$ \\
\hline Hind leg & 63 & 52.50 & More lean \\
Fore leg & 19 & 15.83 & More lean \\
Loin & 10 & 8.33 & More lean \\
Breast & 7 & 5.83 & More lean \\
Rib & 6 & 5.00 & More lean \\
Chump & 4 & 3.33 & More lean \\
Neck & 3 & 2.50 & Price \\
Heart & 2 & 1.67 & Price \\
Liver & 2 & 1.67 & Price \\
Intestine & 2 & 1.67 & Price \\
Head & 2 & 1.67 & Price \\
\hline
\end{tabular}




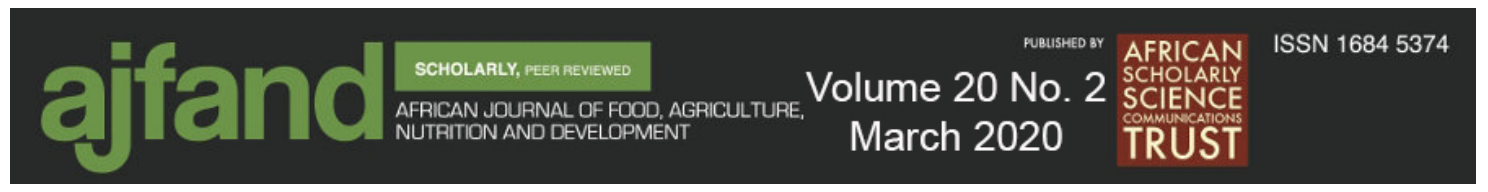

\section{REFERENCES}

1. MLDF (Ministry of Livestock and Fisheries Development). Annual Budget Speech 2011/2012. United Republic of Tanzania, Dodoma. 2012.

2. Chenyambuga SW, Komwihangilo DM and $M$ Jackson Production performance and desirable traits of Small East African goats in semi-arid areas of Central Tanzania. Livest. Res. Rural Dev. 2012; 26:27.

3. Shija DS, Mtenga LA, Kimambo AE, Laswai GH, Mushi DE, Mgheni DM and JG Safari Chemical composition and meat quality attributes of indigenous sheep and goats from traditional production system in Tanzania. Asian-Aust. J Anim. Sci. 2013; 26:295-305.

4. Anaeto M, Adeyeye JA, Chioma GO, Olarinmoye AO and GO Tayo Goat products: Meeting the challenges of human health and nutrition. Agric Biol J N Am. 2010; 1:1231-1236.

5. Sen AR, Santra A and SA Karim Carcass yield, composition and meat quality attributes of sheep and goat under semiarid conditions. Meat Sci. 2004; 66:757763.

6. Mushi DE, Mtenga LA, Eik LO, Safari J and AJ Mwilawa Some factors affecting the quality of meat from ruminants and their relevance to the Tanzania meat industry. In: Tanzania Society Animal Production Conference series, 2006; 32:109-124.

7. Hozza WA, Kifaro GC, Safari JG and DE Mushi Effect of concentrate supplementation levels on growth and slaughter characteristics of SEA and SEA $\times$ Norwegian goats under on-farm conditions. Trop Anim. Health Prod. 2013; 45:1789-1794.

8. Hozza WA, Mtenga LA, Kifaro GC, Shija DSN, Mushi DE, Safari JG and EJM Shirima Meat Quality Characteristics of Small East African Goats and Norwegian Crosses Finished under Small Scale Farming Conditions. Asian-Aust. J Anim Sci. 2014; 27:1773-1782.

9. Mushi DE, Mtenga L.A, Kifaro GC and SW Chenyambuga Influence of sex, age and body condition score on carcass composition and tissue distribution in marketed SEA goats. Tanzania J Agric Sci. 2002; 5:21-28.

10. Mushi DE, Safari J, Mtenga LA, Kifaro GC and LO Eik Effects of concentrate levels on fattening performance, carcass and meat quality attributes of Small East African $\times$ Norwegian crossbred goats fed low quality grass hay. Livest Sci. 2009; 124:148-155. 


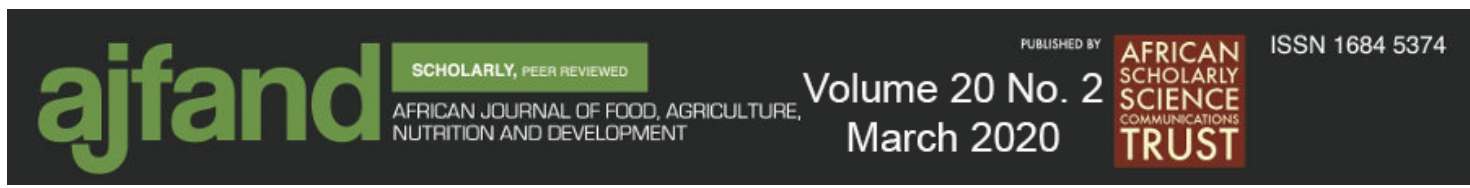

11. Hango A, Mtenga L, Kifaro GC, Safari J, Mushi DE and VRM Muhikambele A study on growth performance and carcass characteristics of Small East African goats under different feeding regimes. Livest Res Rural Dev. 2007; 19:130.

12. Geisler M. Meat Goats Profile.

www.agmrc.org/commodities_products/livestock/goats/meat-goats-profile Accessed 17 October 2018, 2013.

13. Sande DN, Houston JE and JE Epperson The Relationship of Consuming Populations to Meat-Goat Production in the United States. J Food Distrib Res. 2005; 36:156-160.

14. Association of Official Analytical Chemists (AOAC) Official methods of analysis. $17^{\text {th }}$ edition, Arlington, VA, 2000; USA: $69-88$.

15. SAS (Statistical Analysis Systems). SAS User Guide for Personal Computers, Statistical Program, release 9.01. SAS Institute Inc., Cary, NC, 2004.

16. SPSS (Statistical Package for Social Science). SPSS 16.0 for windows, User Manual, SPSS Inc. Chicago, USA, 2003.

17. Attah N, Rouissi $\mathbf{H}$ and $\mathbf{M}$ Mahouachi The effect of dietary protein level on growth, carcass and meat composition of male goat kids in Tunisia. Small Rumin Res. 2004; 54:89-97.

18. Mushi DE Studies on marketing of meat goats and carcass composition: A case study of Gairo auction markets. MSc. Dissertation, Sokoine University of Agriculture, Morogoro, Tanzania. 2004; 153

19. Tshabalala PA, Strydom PE, Webb EC and HL de Kock Meat quality of designated South African indigenous goat and sheep breeds. Meat Sci. 2003; 65:563-570.

20. Webb EC, Casey NH and L Simela Goat meat quality. Small Rumin. Res., 2005; 60:153-166.

21. Sebsibe A, Casey NH, van Niekerk WA, Tegegne A and RJ Coertze Growth performance and carcass characteristics of three Ethiopian goat breeds fed grain less dietary levels varying in concentrate to roughage ratios. S Afr J Anim Sci. 2007; 37:221-232.

22. Assan $\mathbf{N}$ Some factors influencing dressing percentage in goat meat production. Sci Rev J. 2015; 4:156-164.

23. Safari J, Mushi DE, Mtenga LA, Kifaro GC and LO Eik Effects of concentrate supplementation on carcass and meat quality attributes of feedlot finished Small East African goats. Livest Sci. 2009; 125:266-274. 


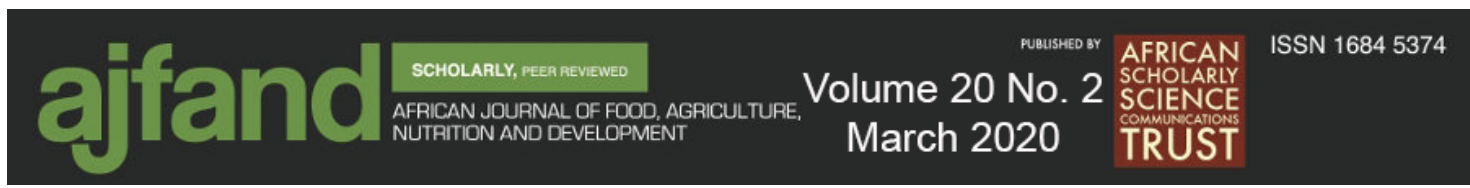

24. El-Waziry AM, Al-Owaimer AN, Suliman GM, Hussein ES and MA Abouheif Performance, carcass characteristics and meat quality of intact and castrated Ardhi goat kids fed high energy diet. J Anim Vet Adv. 2011; 10:2157-2162.

25. Madruga MS, Medeiros EJLD, Sousa WHD, Cunha MDGG, Pereira Filho JM and RDCRD Queiroga Chemical composition and fat profile of meat from crossbred goats reared under feedlot systems. R Bras Zootec. 2009; 38:547-552.

26. Lee JH, Kouakou $\mathbf{B}$ and $\mathbf{G}$ Kannan Chemical composition and quality characteristics of chevon from goats fed three different post-weaning diets. Small Rumin Res. 2008; 75:177-184.

27. Berihun K, Banerjee $\mathbf{S}$ and $\mathbf{S}$ Yigrem Carcass traits of Arsi-bale sheep and goat reared under farmers management system in Sidama Region of Southern Ethiopia. Middle East J Sci Res. 2013; 13:1465-1470.

28. Dhanda JS, Taylor DG, Murray PJ, Pegg RB and PJ Shand Goat meat production: present status and future possibilities. Asian-Aust J Anim Sci. 2003; 16:1842-1852.

29. Hill JI Consumers' preferences for goat meat in the United States: an application of choice-based conjoint analysis. LSU Doctoral Dissertations. 1460. http://digitalcommons.lsu.edu/gradschool dissertations/1460, 2013; 12.

30. Msanga YN, Mbaga SH and JK Msechu Farm Animal Breeds and Strains of Tanzania. In: Kifaro GC, Kurwijila RL (ed), The Proceedings of SUA-MU ENRECA Project Workshop, Morogoro, Tanzania. 2001; 36-49.

31. Chenyambuga SW, Watts PC, Hirbo J, Kemp SJ and O Hanotte Analysis of genetic diversity and relationships of Tanzanian local goat populations using microsatellite DNA markers. Tanzania J Agric Sci. 2002; 5:29-38.

32. Nguluma AS, Msalya G and SW Chenyambuga Phenotypic variation among four populations of small East African goats of Tanzania. Livest Res Rural Dev. 2016; 28:136.

33. Semuguruka YD and DM Komwihangilo Factors affecting production and productivity of goat and sheep meat in semi-arid in Dodoma. In: Tanzania Soc. Anim. Prod. Conference series, 2009; 33: 321-333. 